\title{
Complications associated with the use of flow-diverting devices for cerebral aneurysms: a systematic review and meta-analysis
}

\author{
Geng Zhou, PhD, ${ }^{1}$ Ming Su, MD, ${ }^{2}$ Yan-Ling Yin, MD, ${ }^{3}$ and Ming-Hua Li, PhD1 \\ 1Department of Diagnostic and Interventional Radiology, Shanghai Jiao Tong University Affiliated Sixth People's Hospital, \\ Shanghai; ${ }^{2}$ Shandong Academy of Chinese Medicine, Lixia, Jinan; and ${ }^{3}$ Department of Anesthesiology, The Military General \\ Hospital of Beijing PLA, Beijing, China
}

OBJECTIVE The objective of this study was to review the literature on the use of flow-diverting devices (FDDs) to treat intracranial aneurysms (IAs) and to investigate the safety and complications related to FDD treatment for IAs by performing a meta-analysis of published studies.

METHODS A systematic electronic database search was conducted using the Springer, EBSCO, PubMed, Medline, and Cochrane databases on all accessible articles published up to January 2016, with no restriction on the publication year. Abstracts, full-text manuscripts, and the reference lists of retrieved articles were analyzed. Random-effects metaanalysis was used to pool the complication rates across studies.

RESULTS Sixty studies were included, which involved retrospectively collected data on 3125 patients. The use of FDDs was associated with an overall complication rate of $17.0 \%(95 \%$ confidence interval $[\mathrm{Cl}] 13.6 \%-20.5 \%)$ and a low mortality rate of $2.8 \%(95 \% \mathrm{Cl} 1.2 \%-4.4 \%)$. The neurological morbidity rate was $4.5 \%(95 \% \mathrm{Cl} 3.2 \%-5.8 \%)$. No significant difference in the complication or mortality rate was observed between 2 commonly used devices (the Pipeline embolization device and the Silk flow-diverter device). A significantly higher overall complication rate was found in the case of ruptured IAs than in unruptured IA (odds ratio $2.3,95 \% \mathrm{Cl} 1.2-4.3$ ).

CONCLUSIONS The use of FDDs in the treatment of IAs yielded satisfactory results with regard to complications and the mortality rate. The risk of complications should be considered when deciding on treatment with FDDs. Further studies on the mechanism underlying the occurrence of adverse events are required.

https://thejns.org/doi/abs/10.3171/2017.3.FOCUS16450

KEY WORDS intracranial aneurysm; flow-diverting device; complication; delayed rupture

$\mathrm{F}$ LOW-DIVERTING devices (FDDs) are a groundbreaking invention in the treatment of intracranial aneurysms (IAs). Since their inception in 2007, FDDs have revolutionized the treatment of IAs by replacing the earlier endosaccular approach with an endoluminal strategy. ${ }^{44}$ Currently, parent vessel reconstruction with FDDs is rapidly becoming the preferred endovascular modality for giant and complex IAs. ${ }^{7}$ In some areas, FDD application has drastically decreased the rate of coil and stent usage. ${ }^{21}$

Despite the large number of reports on successful treatment of aneurysms with flow diverters, various unpredictable adverse events have also been reported. Moreover, there is a dearth of studies on the complications associated with this technique. To date, the safety issues and compli- cations related to FDDs have not been fully evaluated. Few studies have comprehensively investigated the clinical and technical events in the use of flow diverters for the treatment of IAs. We therefore performed this meta-analysis to evaluate the overall morbidity and mortality rates associated with this endovascular technique. The purpose of this study is to investigate the overall complication rates for different patient cohorts.

\section{Methods \\ Literature Search}

We used the search strategies recommended in the Cochrane Handbook for Systematic Reviews of Interventions.

ABBREVIATIONS BA = basilar artery; $\mathrm{Cl}=$ confidence interval; FDD = flow-diverting device; $\mathrm{IA}$ = intracranial aneurysm; ISS = in-stent stenosis; $\mathrm{MCA}=$ middle cerebral artery; $\mathrm{OR}=$ odds ratio; $\mathrm{PED}=$ Pipeline embolization device; $\mathrm{SAC}=$ stent-assisted coiling; $\mathrm{SAH}$ = subarachnoid hemorrhage.

SUBMITTED October 30, 2016. ACCEPTED March 28, 2017.

INCLUDE WHEN CITING DOI: 10.3171/2017.3.FOCUS16450. 


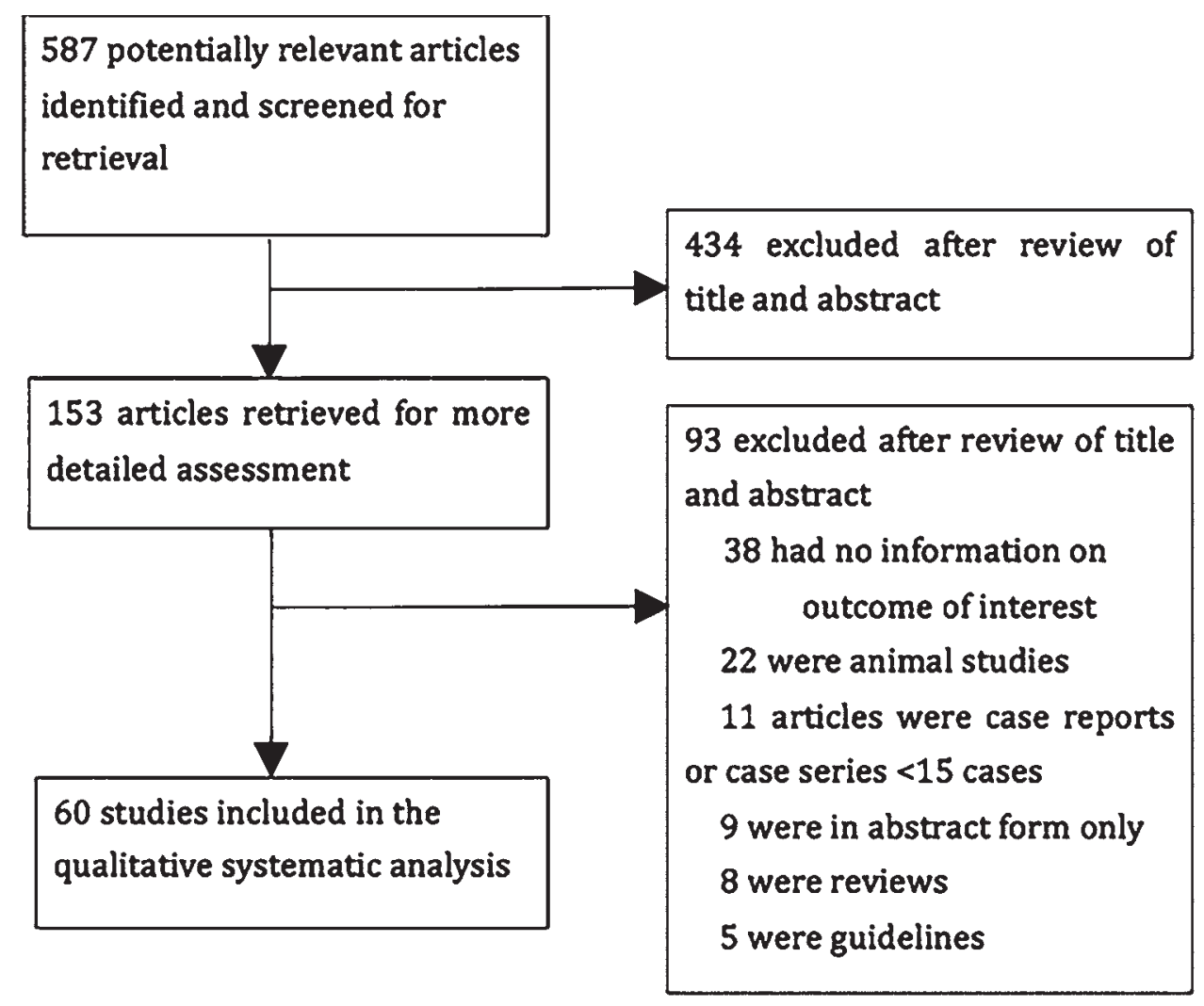

FIG. 1. Flow diagram of the selection of articles.

Titles, abstracts, key words, and free text were searched using combinations of the following key words: "intracranial aneurysm*," "cerebral aneurysm*," "flow divert*," "complication*," "morbidity," and "mortality." The Springer, EBSCO, MEDLINE, Cochrane, and PubMed databases were searched using the specified key words. We also manually searched the references of review articles for additional studies. The decision on whether a study should be included was made independently by 2 authors (G.Z. and M.S.). Data were obtained from the included articles by 1 investigator and reviewed for accuracy by a second investigator. At each step, disagreements were settled by the senior author (M.-H.L.).

\section{Inclusion and Exclusion Criteria}

This analysis included: 1) studies on at least 15 patients undergoing IA treatment with an FDD; 2) studies with data on periprocedural and delayed complications; and 3) English language studies. In addition, the following were excluded: 1) studies that were not published in full; and 2) editorials, letters, review articles, guidelines, case reports, in vitro studies, and studies on animal experimentation.

\section{Data Extraction}

Using a prespecified form of data abstraction, 2 investigators (G.Z. and M.S.) independently evaluated all the studies and abstracted the following information: 1) study characteristics; 2) patient characteristics (number of patients, demographics, and clinical characteristics); 3) eligibility, based on the abovementioned study selection criteria; 4) mortality and morbidity; 5) adverse technical events; 6) treatment devices; and 7) location of the aneurysms. We also categorized adverse procedural events as follows: symptomatic ischemic events, hemorrhagic events, and symptoms derived from mass effect.

\section{Quality Assessment and Statistical Analysis}

This meta-analysis was performed using the software package Stata (version 13.0, StataCorp). The pooled data were subjected to a random-effects meta-analysis with 95\% confidence intervals (CIs). Dichotomous variables were presented as odds ratios (ORs) with a 95\% CI. Significance was set at $\mathrm{p}<0.05$. To assess the heterogeneity in the results of individual studies, we used the $\mathrm{I}^{2}$ statistic. Funnel plots were used to screen for potential publication bias. The selected cutoff number of 15 patients was based on the assumption that very small study cohorts probably lack statistical power in their outcome analyses. The complications were divided into 3 categories of minor, intermediate, and severe. Minor complications consisted of minor ischemic events (including distal emboli and transient ischemic attack), transient dysphasia, and access site complications without need for transfusion. The intermediate complications comprised visual impairment, dissections, in-stent stenosis (ISS), branch occlusion, poor stent opening, wire perforation, deployment failure, and device migration or poor position. Severe complications consisted of ipsilateral parenchymal hemorrhage, rebleeding, and major stroke. 


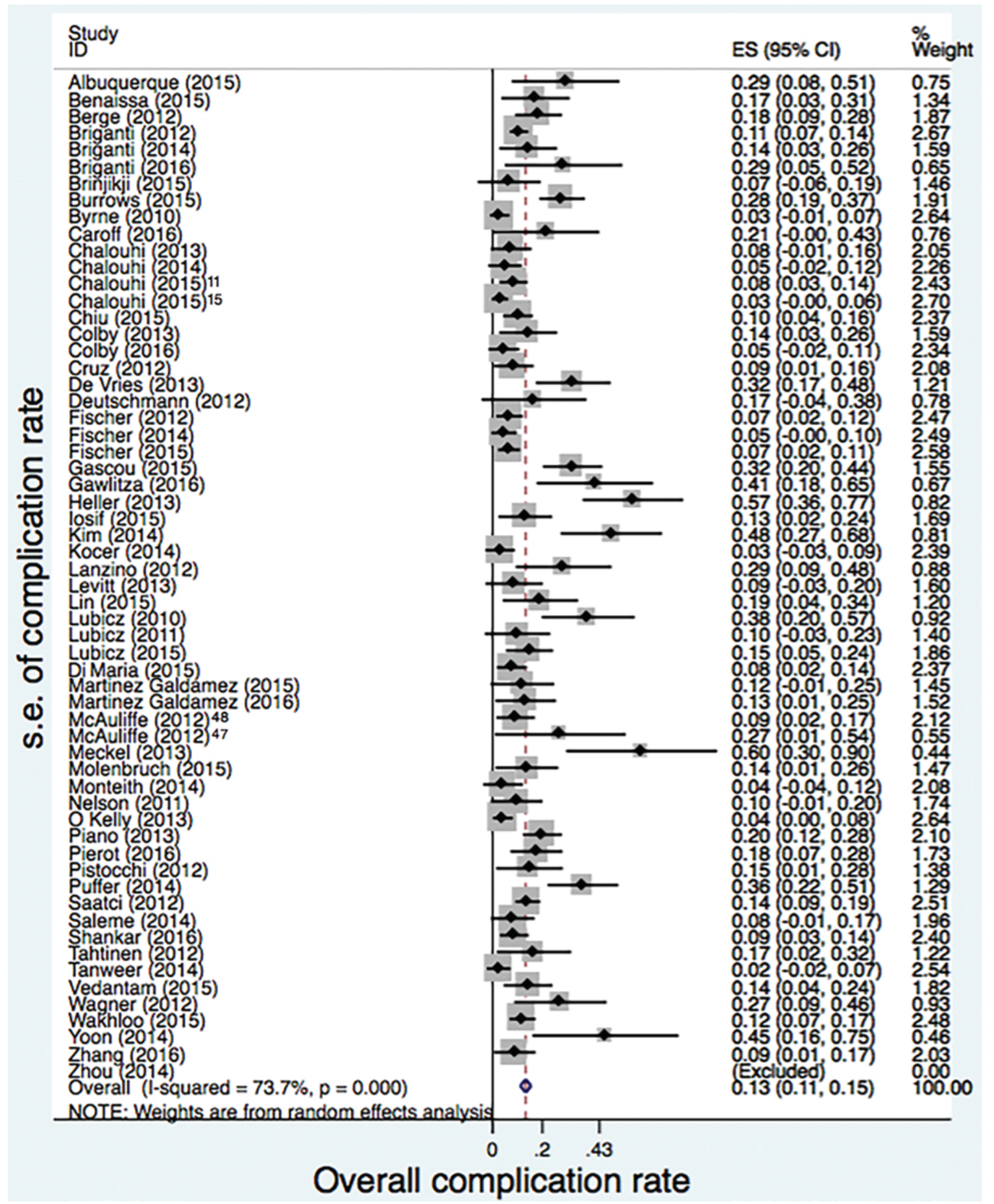

FIG. 2. Meta-analysis of the reported complication rate of FDDs. A random-effects model was applied. ES = effect size; s.e. = standard error.

\section{Results}

\section{Study Selection}

A total of 587 articles were obtained from the literature search. After screening the abstracts, we selected 153 complete papers that reported data on the complications associated with FDDs for the treatment of IAs in case se-

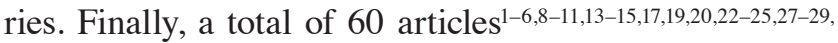
$31-33,35-40,42,43,45-48,52,53,55-57,59,61,63,66,67,69,73-77,80,81,84$ met all the inclusion criteria and were included and reviewed thoroughly (Figs. 1 and 2). No new studies were found by a manual search of the reference list. In total, 3125 patients and 3427 treated aneurysms were included in the analysis (Table 1). 


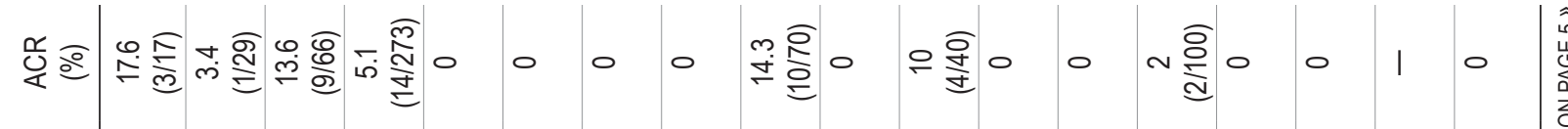

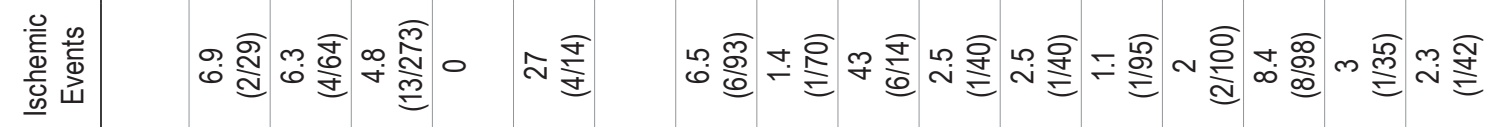

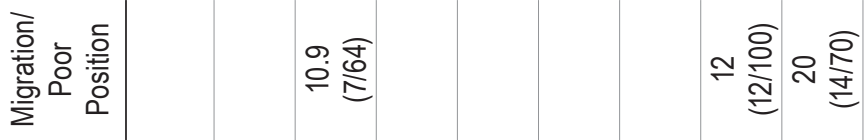

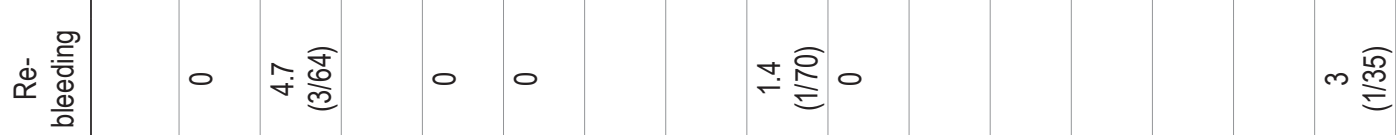

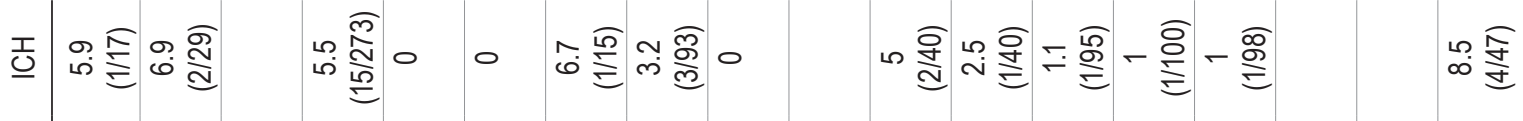
高

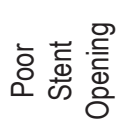
(1)

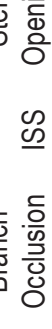

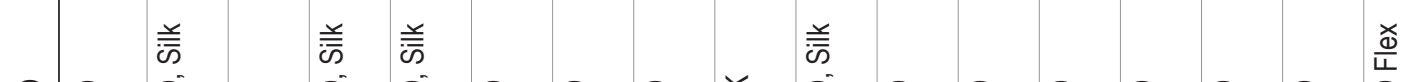

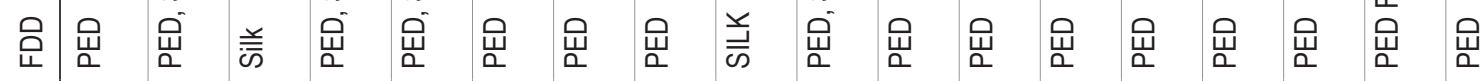

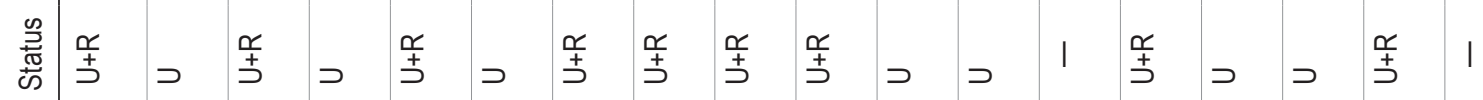

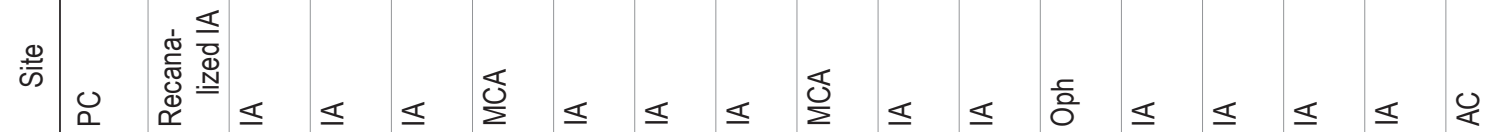
产

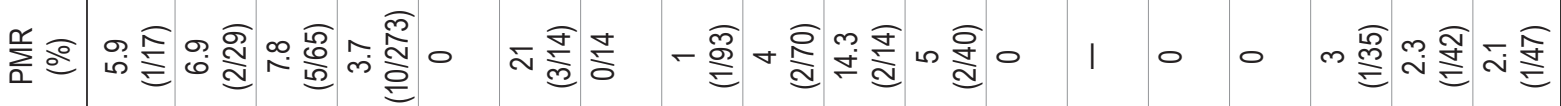

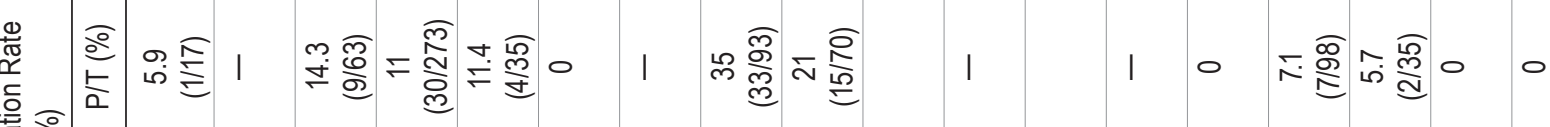

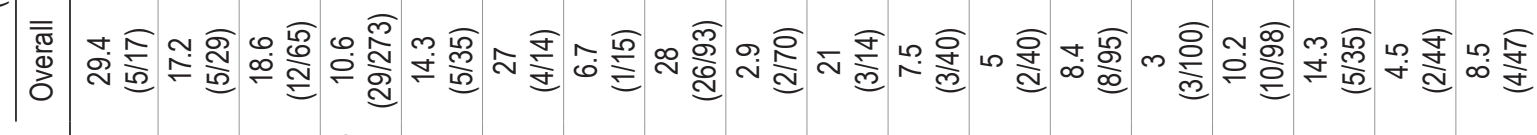

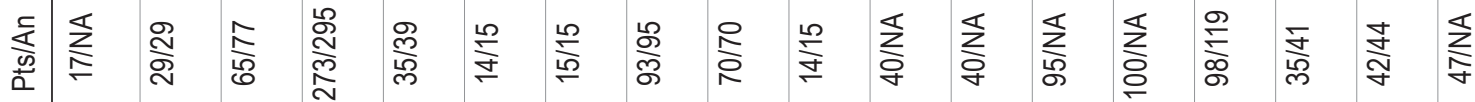

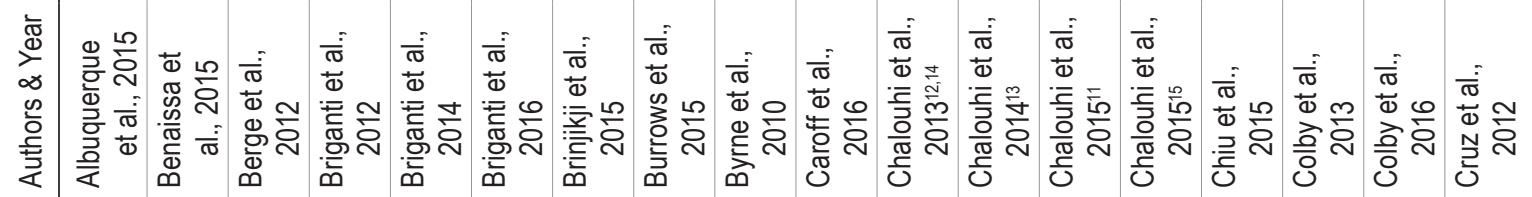




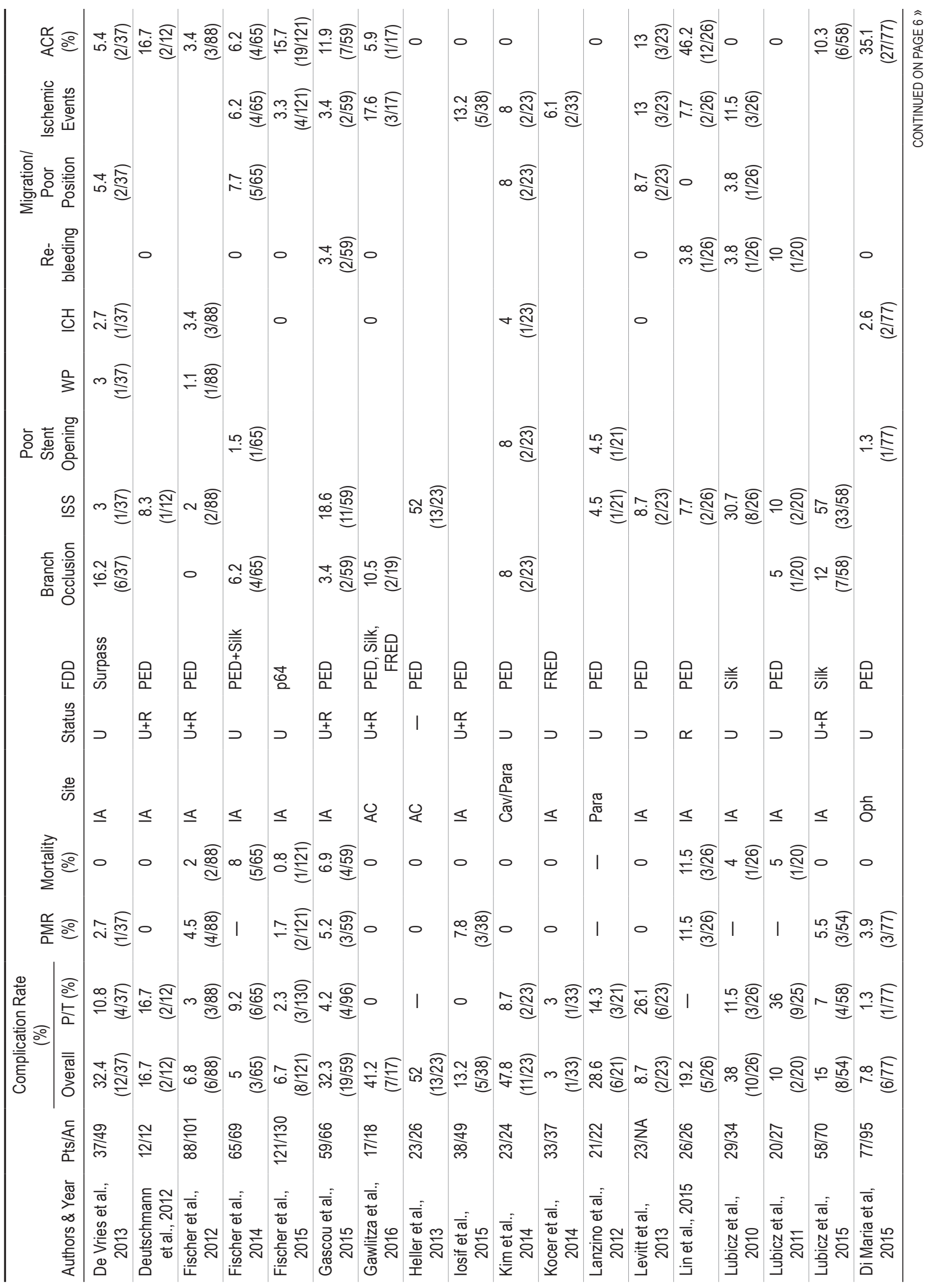




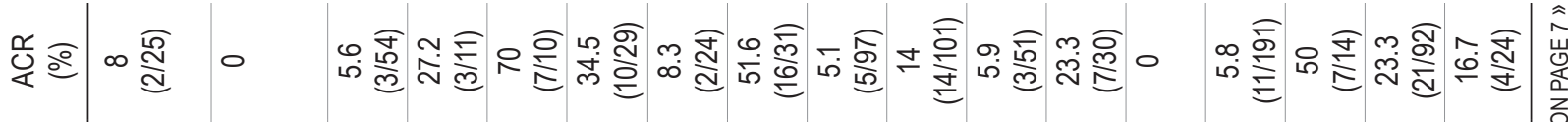

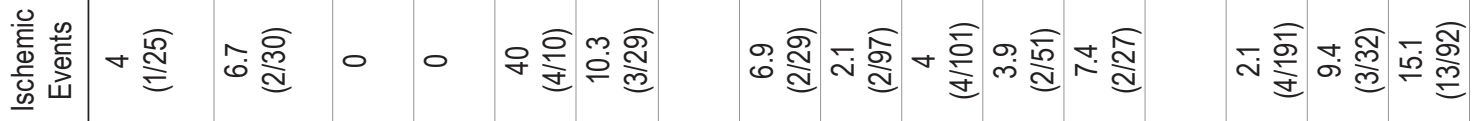

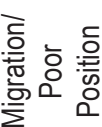

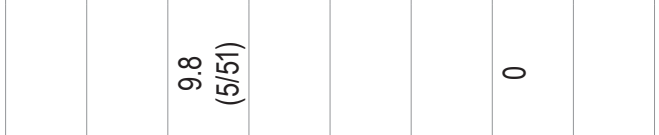

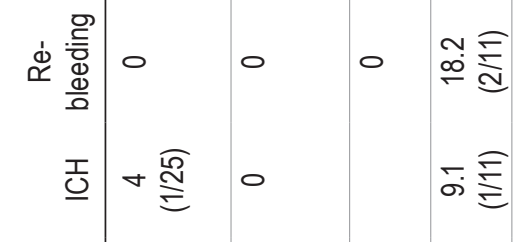

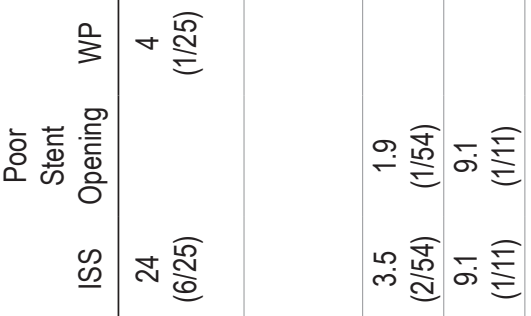

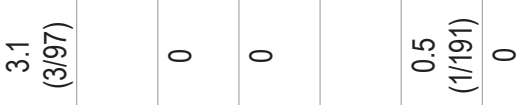

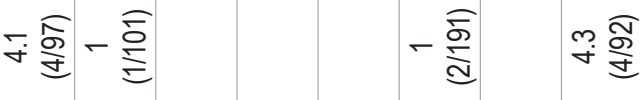

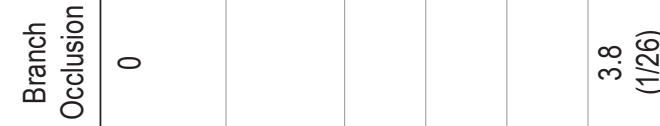

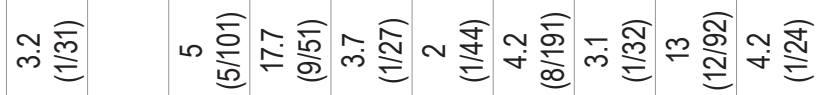

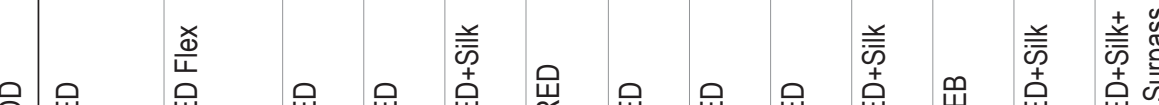

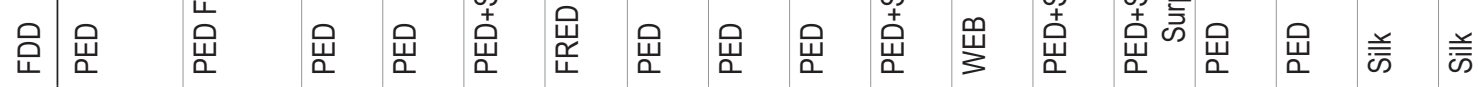

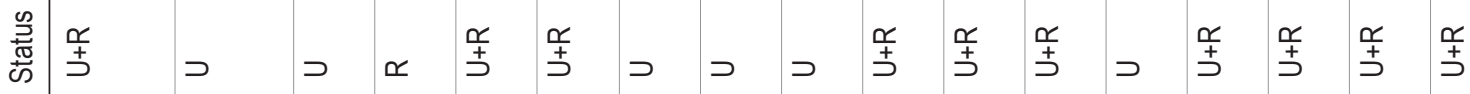
兽 旁

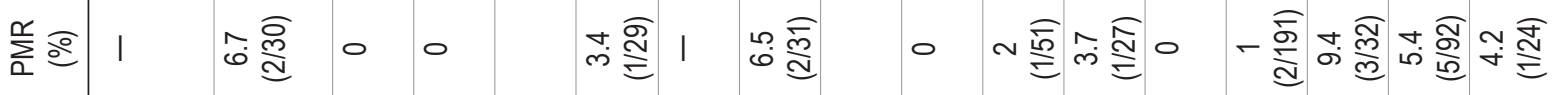

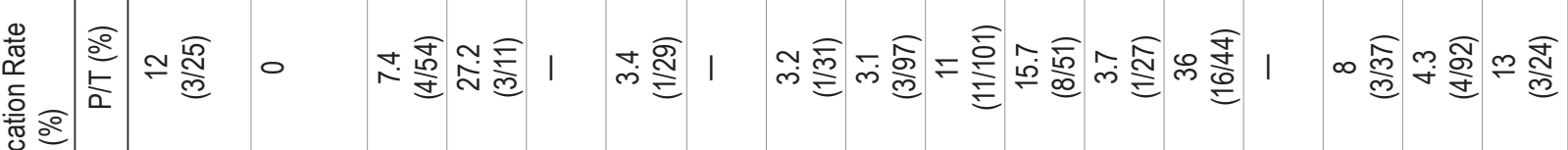
O)

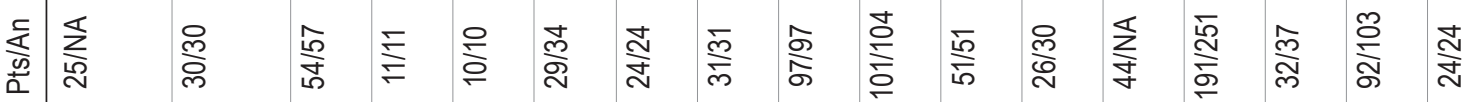

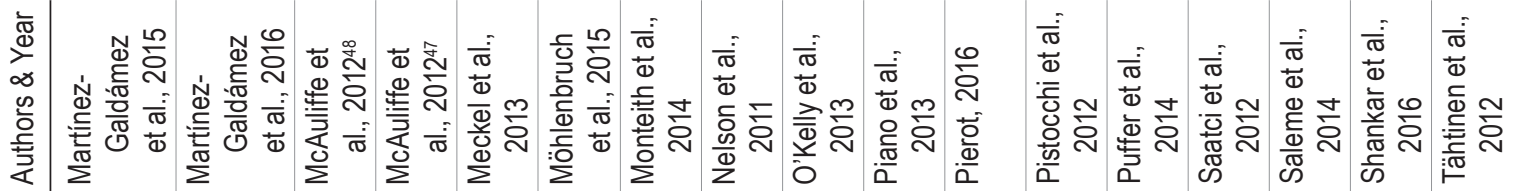




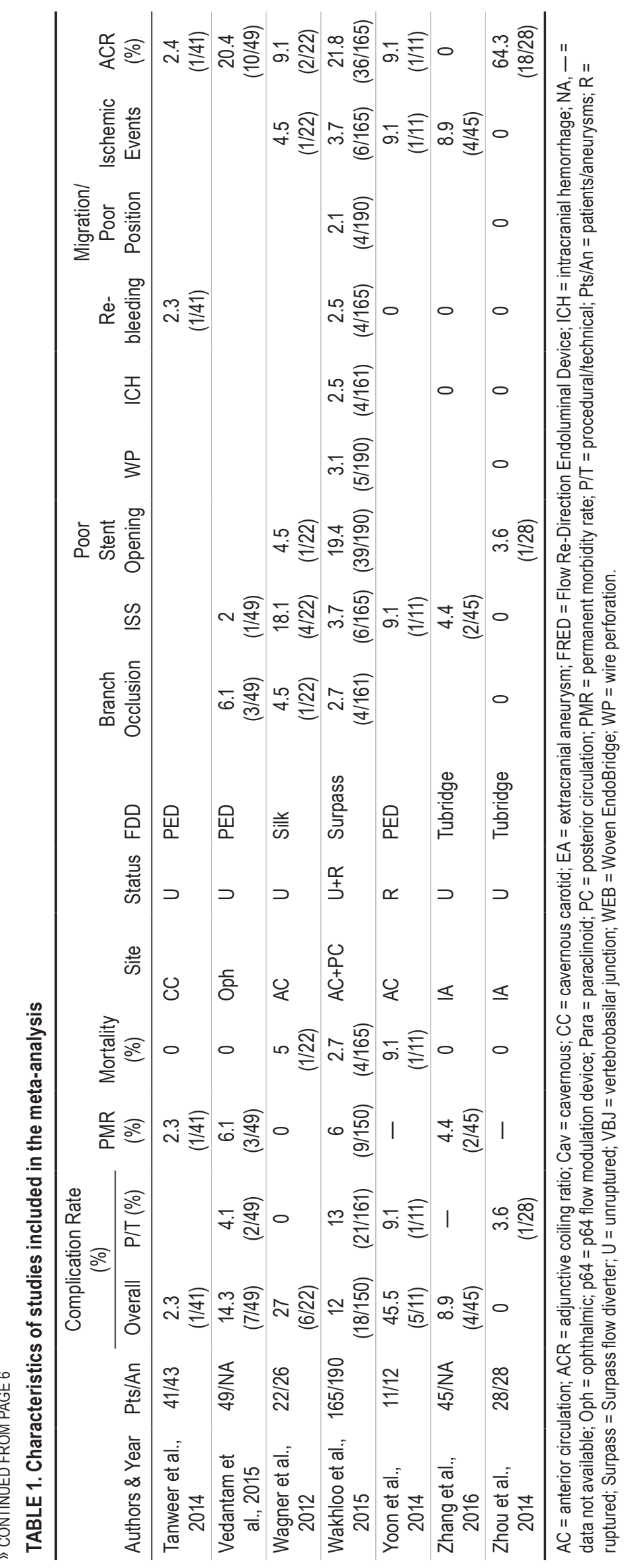


TABLE 2. Summary of complication and mortality rates of FDDs stratified by different categories

\begin{tabular}{|c|c|c|c|c|c|c|c|}
\hline \multirow[b]{2}{*}{ Complication } & \multicolumn{6}{|c|}{$\%$ Type of Device } & \multirow{2}{*}{$\begin{array}{c}\% \text { (Total) } \\
\text { of All } \\
\text { Complications }\end{array}$} \\
\hline & $\begin{array}{c}\text { PED } \\
(n=1570)\end{array}$ & $\begin{array}{c}\text { Silk } \\
(n=360)\end{array}$ & $\begin{array}{l}\text { FRED } \\
(n=62)\end{array}$ & $\begin{array}{l}\text { Surpass } \\
(\mathrm{n}=202)\end{array}$ & $\begin{array}{l}\text { Multiple Devices } \\
\qquad(\mathrm{n}=614)\end{array}$ & $\begin{array}{l}\text { Other Devices } \\
\quad(n=317)\end{array}$ & \\
\hline Minor & $3.7(58)$ & $0.2(1)$ & $4.8(3)$ & $5.9(12)$ & $2(12)$ & $3.2(10)$ & $16.1(96 / 596)$ \\
\hline Intermediate & $13.7(215)$ & $15(54)$ & 0 & $34.7(70)$ & $5.7(35)$ & $12(38)$ & $69.1(412 / 596)$ \\
\hline Severe & $3.1(49)$ & $2.2(8)$ & $4.8(3)$ & $4(8)$ & $2.4(15)$ & $1.6(5)$ & $14.8(88 / 596)$ \\
\hline Death & $1.8(29)$ & $2.8(10)$ & 0 & $2(4)$ & $4.6(28)$ & $0.3(1)$ & \\
\hline
\end{tabular}

\section{Complication Rates}

The overall complication rate was $17.0 \%$ (95\% CI $13.6 \%-20.5 \%)$. The incidence of procedural technical complications was $9.4 \%$ (95\% CI 6.6\%-12.2\%). The specific causes of the technical events were poor stent opening (in $8.6 \%$ of the cases, $95 \%$ CI $4.6 \%-12.7 \%$ ) and wire perforation (in $3.8 \%$ of the cases, 95\% CI $0.73 \%-6.87 \%$; Table 1). Adverse events were classified and the rates were $14.8 \%$ for severe complications, $69.1 \%$ for intermediate adverse events, and $16.1 \%$ for minor complications (Table 2). The overall complication rate was found to be associated with the rupture status of the aneurysm (Table 3). The complication rate for unruptured IAs was $14.6 \%(95 \%$ CI 9.8\%-19.4\%), which was significantly lower than that for ruptured IAs $(30.6 \%, \mathrm{p}<0.05)$. A significantly higher overall complication rate was found in the case of ruptured IAs than unruptured IAs (OR 2.3, 95\% CI 1.2-4.3). Figure 3 summarizes the complication rates associated with commonly used devices: the Pipeline embolization device (PED; Covidien) was associated with a slightly lower complication rate than the Silk flow-diverter stent (Balt Extrusion; $16.0 \%$ vs $18.1 \%$, Table 4). Our present findings indicate the overall complication rate in posterior circulation IAs was $44.7 \%$, which was significantly higher than that for anterior circulation IAs $(23.7 \%$, 95\% CI $15.4 \%-$ $31.9 \%$; Table 5). The neurological morbidity rate was $4.5 \%$ (95\% CI 3.2\%-5.8\%). The specific causes were ischemia $(7.5 \%, 95 \%$ CI $4.9 \%-10.2 \%)$, rebleeding $(1.8 \%, 95 \%$ CI $0.5 \%-3.2 \%)$, and intracranial hemorrhages $(2.9 \%, 95 \%$ CI $1.9 \%-3.9 \%$ ). The permanent morbidity rate and mortality rates were $3.7 \%(95 \% \mathrm{CI} 2.5 \%-4.9 \%)$ and $2.8 \%(95 \% \mathrm{CI}$ $1.2 \%-4.4 \%$ ), respectively. Analyses of complications and FDDs were associated with substantial heterogeneity $\left(\mathrm{I}^{2}>\right.$ $50 \%$ ), suggesting unexplained differences in study populations and procedures (Fig. 4).

\section{Discussion}

In this paper, we report findings from the largest metaanalysis conducted to date of complications related to FDD

TABLE 3. Overall complication rates obtained for different types of SAH

\begin{tabular}{lcc}
\hline \multicolumn{1}{c}{ SAH Type } & Rate $(\%)$ & $95 \% \mathrm{Cl}$ \\
\hline Only unruptured IAs & 14.6 & $9.8-19.4$ \\
\hline Only ruptured IAs & 30.6 & - \\
\hline Unruptured \& ruptured IAs & 17.4 & $16.8-22.5$ \\
\hline
\end{tabular}

treatment for IAs. Although some heterogeneity was found in the results of the studies that were included, the current published data suggest that aneurysms treated with FDDs have a low complication rate. There is a dearth of studies on the safety and morbidity related to this technique, so the information added by this study will be valuable.

In several recent data analyses, the morbidity and mortality rates were reported as $2.8 \%-14.1 \%$ and $0 \%-3.7 \%$, respectively, with a permanent morbidity rate of $1.3 \%-$ $6.3 \% .^{7,83}$ Our study has several merits compared with the previously published articles. First, because our study includes all available studies in this important field, it presents a complete overview of all available evidence on the adverse events in FDD strategies. We were able to include a larger number of studies due to the rapid growth of the field. We are therefore able to provide the most conclusive overview currently available. Second, we divided the complications into 3 categories of minor, intermediate, and severe. The presented systematic review and results of the meta-analysis investigating the relationship between FDD placement and adverse events is the most comprehensive assessment of this relationship to date. Our findings demonstrated an overall complication rate of $17 \%$, with a permanent morbidity rate of $3.7 \%$ and a mortality rate of $2.8 \%$.

Delayed complications associated with the implantation of FDDs have tempered enthusiasm for their widespread use. ${ }^{18}$ Rupture of aneurysms after FDD treatment is rare $(1.8 \%)$. This probably reflects the balance between complete aneurysm thrombus formation and thrombosismediated inflammatory disruption of the aneurysmal wall..$^{30}$ Xiang et al. ${ }^{78}$ also suggest that stagnant aneurysmal flow and excessively low wall shear stress may promote wall degradation via the inflammatory pathway.

Current reports ${ }^{24}$ have not shown any evidence suggesting that FDDs may induce a pressure change that could lead to rupture of the aneurysm. Moreover, Schneiders et al. ${ }^{68}$ argue that the wall of the still-perfused aneurysm has to endure hemodynamic stress caused by the cardiac pulse wave, which again might contribute to rupture in a later phase. In our analysis, the reported incidence of delayed ruptures is slightly higher with the Silk FDD than with the PED (3.6\% vs $3.3 \%)$.

The complication rate for unruptured aneurysms $(14.6 \%)$ was significantly lower than that for ruptured IAs $(30.6 \%, \mathrm{p}<0.05)$. This result indicated that the aneurysm is not immediately protected after treatment by FDDs, which often leads to complete occlusion in 3-12 months. Patients need antiplatelet medication after FDD insertion, 


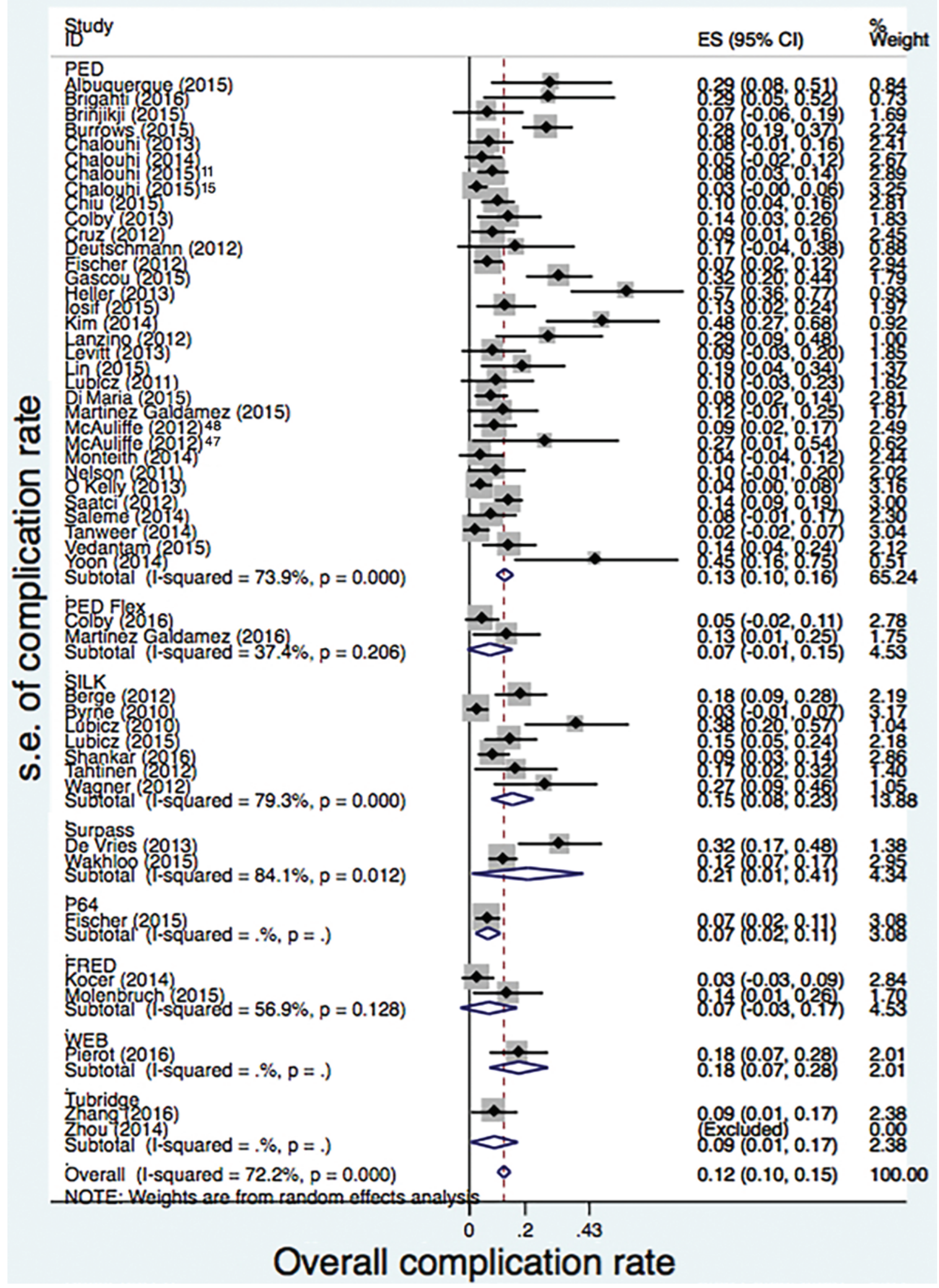

FIG. 3. Forest plot of complication rates comparing different types of FDDs. FRED = Flow Re-Direction Endoluminal Device; WEB $=$ Woven EndoBridge. 
TABLE 4. Overall complication rate obtained with commonly used FDDs at last follow-up

\begin{tabular}{lcc}
\hline \multicolumn{1}{c}{ FDD } & Complication Rate $(\%)$ & $95 \% \mathrm{Cl}$ \\
\hline PED & 16.0 & $11.2-20.8$ \\
\hline Silk & 18.1 & $7.4-28.8$ \\
\hline FRED & 8.4 & \\
\hline Surpass & 22.2 & \\
\hline PED Flex & 29.4 & \\
\hline p64 & 6.7 & \\
\hline Tubridge & 4.45 \\
\hline
\end{tabular}

potentially increasing the rebleeding risk for ruptured aneurysms. Thus, the use of FDDs in the acute subarachnoid hemorrhage (SAH) stage poses a major clinical challenge. Larger case series are needed to define the safety role of FDD application in these kinds of clinical situations. ${ }^{25,54}$

In our analysis, the overall ratio of adjunctive coiling was $12.3 \%$. The safety and efficacy of PED placement have to be compared with that of conventional endovascular therapy. Our previous study compared the PED with coil embolization and stent-assisted coiling (SAC), and demonstrated that PED placement did not show a significant difference in morbidity and mortality between the two techniques ${ }^{83}$ The complications of coiling and SAC are essentially limited to thromboembolic events and aneurysmal rupture, and the total event rates ranged between $3 \%$ and $21 \%$. Most of the complications in the series were asymptomatic, and permanent morbidity rates ranged between $0 \%$ and $10 \%{ }^{60,65,70,71,75}$ However, SAC of acutely ruptured aneurysms is associated with significantly higher complication rates $(5 \%-25 \%$ vs $0 \%-16 \%)$ than unruptured aneurysms. ${ }^{12,42,75}$ Mortality rates ranged from $0 \%$ to $4.6 \%$ and $0 \%$ to $20 \%$ in ruptured cases..$^{51,75}$ Major concerns with
TABLE 5. Relation between overall complication rate and aneurysm location

\begin{tabular}{ccc}
\hline Site & Rate $(\%)$ & $95 \% \mathrm{Cl}$ \\
\hline Anterior circulation & 23.7 & $15.4-31.9$ \\
\hline MCA & 24 & \\
\hline Ophthalmic segment & 8.1 & \\
\hline Supraclinoid segment & 21.5 & \\
\hline Cavernous carotid & 25.1 & \\
\hline Posterior circulation & 44.7 & \\
\hline Vertebrobasilar junction & 60 \\
\hline
\end{tabular}

coiling are coil prolapse into the parent vessel and coil penetration, which is estimated to be $2.5 \% .^{72}$ Procedurerelated complications were comparable in the SAC group and the coiling-alone group. ${ }^{34}$ Delayed (30-day) ISS or occlusion following SAC was reported to be $3.4 \%-5.8 \% .^{26,50}$

At present, the time frame for complete occlusion of an aneurysm is unknown. To prevent complications, aneurysm occlusions need to be stabilized as soon as possible. The process of aneurysm occlusion after FDD placement is also linked in part to the antiplatelet regimen administered. ${ }^{73}$

Potential occlusion of the side branches or perforating arteries carries the risk of secondary ischemic complications. Further, overlap of FDDs potentially increases the risk of arterial branch or perforator occlusion and may be responsible for ischemic complications. ${ }^{76}$ The branch occlusion rate was found to be $4.9 \%$ (95\% CI 3.2\%-6.6\%). Only a few studies have examined the effect of FDDs on side branches. Yavuz et al. ${ }^{79}$ reported that perforators from the middle cerebral artery (MCA) or those from the basilar artery (BA) usually remain patent after FDD placement. However, occlusions may still occur. A previ-

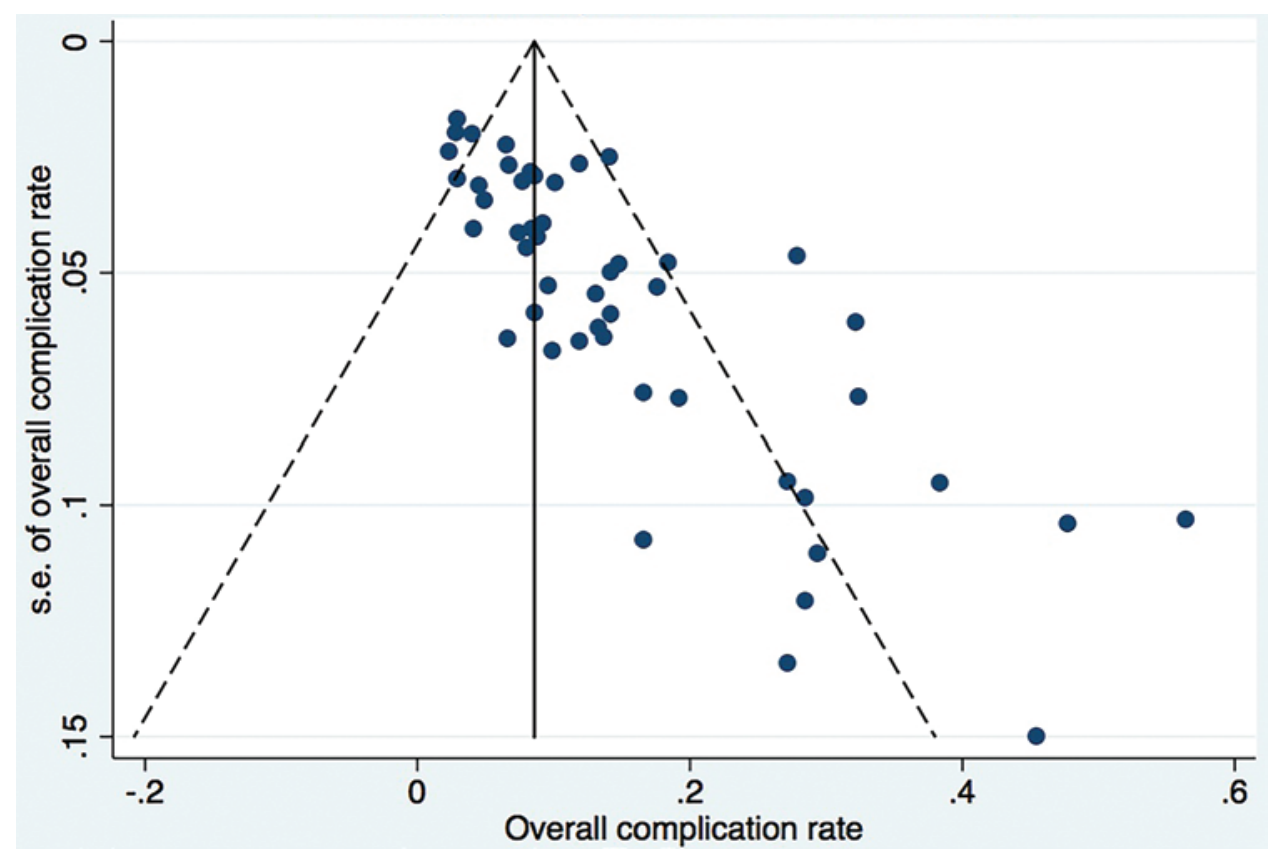

FIG. 4. Funnel plot of the reported rate of complications. Publication biases are evident. 
ous report found an alarmingly high correlation between perforator infarction and posterior location of IAs. Most side branch occlusion events have been reported to occur in patients who were treated with more than 2 flow diverters or stents. ${ }^{58}$ Although covering the arterial branch with an FDD may lead to gradual occlusion over time, the vascular territory it supplies could be fed by collateral arterial connections, and most patients were asymptomatic. ${ }^{62}$

Migration or poor position rate was 5.8\% (95\% CI $3.7 \%-8.0 \%$ ) in the analysis. Fischer et al. ${ }^{28}$ demonstrated that implantation of an undersized device carries a potential risk of an endoleak-like phenomenon..$^{29} \mathrm{~A}$ compliant balloon could be used if the deployed FDD shows poor wall apposition. Moreover, Lubicz et al. ${ }^{41}$ recommended a stent diameter that is $0.25-0.5 \mathrm{~mm}$ larger than the distal parent vessel diameter. Foreshortening of up to $60 \%$ of the flow diverter is possible during implantation, but careful size and length selection is important. ${ }^{37,82}$ Stent placement across a fusiform aneurysm must be performed with more vigilance, as stent anchorage relies on a small surface area for contact with the parent artery. ${ }^{64}$

De Vries et al. ${ }^{24}$ considered patients with stenosis after device implantation to be at high risk of in-stent thrombosis on discontinuation of clopidogrel. Cohen et al. reported that ISS was observed in $38 \%$ of the cases in which the Silk device was used and 39\% of the cases in which PEDs were used. ISS was asymptomatic in 12 of 13 patients. ${ }^{18}$ No exact duration of treatment, or the best combination for prophylactic platelet inhibition drugs, has been established, which has highlighted the need for better evidence for tailoring antiplatelet therapy ${ }^{16}$ An ISS rate of $10.1 \%$ was found in our analysis.

In the case of posterior circulation aneurysms, Meckel et al ${ }^{49}$ suggested that FDD strategies are associated with significant risk and therefore should be reserved for cases in which alternative approaches are deemed unsafe or ineffective. Our present findings indicate the overall complication rate in posterior circulation aneurysms was $44.7 \%$, which was significantly higher than that for anterior circulation IAs (23.7\%).

Our study has several limitations that should be considered. First, the prevalence of risk factors and clinical presentations may differ across participants of various studies, so there is a possibility of a confounding bias. Given this, the overall quality of evidence of this systematic review could be considered as low. We have tried to minimize the effect of such a bias by selecting larger case series with 15 or more patients. Second, most of the selected studies were retrospective. Documentation of complications was collected from medical charts. It is likely that minor complications that did not require event reporting or operative intervention were not taken into account in the published literature.

\section{Conclusions}

According to the preliminary series, the complication and mortality rates associated with the use of FDDs appears to be satisfactory, specifically in the context of complex aneurysms. However, the mechanism of delayed rupture after flow diversion must be analyzed so that the appropriate perioperative medication and optimal method for implantation can be determined. More studies, including randomized trials, are needed to provide accurate data on the safety of the flow diversion technique.

\section{Acknowledgments}

This study was supported by grants from the National Natural Science Foundation of China (nos. 81471760 and 81671655). Dr. Li is the guarantor of integrity for the entire study.

\section{References}

1. Albuquerque FC, Park MS, Abla AA, Crowley RW, Ducruet AF, McDougall CG: A reappraisal of the Pipeline embolization device for the treatment of posterior circulation aneurysms. J Neurointerv Surg 7:641-645, 2015

2. Benaissa A, Januel AC, Herbreteau D, Berge J, Aggour M, Kadziolka K, et al: Endovascular treatment with flow diverters of recanalized and multitreated aneurysms initially treated by endovascular approach. J Neurointerv Surg 7:44-49, 2015

3. Berge J, Biondi A, Machi P, Brunel H, Pierot L, Gabrillargues J, et al: Flow-diverter silk stent for the treatment of intracranial aneurysms: 1-year follow-up in a multicenter study. AJNR Am J Neuroradiol 33:1150-1155, 2012

4. Briganti F, Delehaye L, Leone G, Sicignano C, Buono G, Marseglia M, et al: Flow diverter device for the treatment of small middle cerebral artery aneurysms. J Neurointerv Surg 8:287-294, 2016

5. Briganti F, Napoli M, Leone G, Marseglia M, Mariniello G, Caranci F, et al: Treatment of intracranial aneurysms by flow diverter devices: long-term results from a single center. Eur J Radiol 83:1683-1690, 2014

6. Briganti F, Napoli M, Tortora F, Solari D, Bergui M, Boccardi E, et al: Italian multicenter experience with flow-diverter devices for intracranial unruptured aneurysm treatment with periprocedural complications - a retrospective data analysis. Neuroradiology 54:1145-1152, 2012

7. Brinjikji W, Fallmes DF, Cloft HJ, Lanzino G: Patency of the anterior choroidal artery after flow-diversion treatment of internal carotid artery aneurysms. AJNR Am J Neuroradiol 36:537-541, 2015

8. Burrows AM, Cloft H, Kallmes DF, Lanzino G: Periprocedural and mid-term technical and clinical events after flow diversion for intracranial aneurysms. J Neurointerv Surg 7:646-651, 2015

9. Byrne JV, Beltechi R, Yarnold JA, Birks J, Kamran M: Early experience in the treatment of intracranial aneurysms by endovascular flow diversion: a multicentre prospective study. PLoS One 5:e12492, 2010

10. Caroff J, Neki H, Mihalea C, D’Argento F, Abdel Khalek H, Ikka L, et al: Flow-diverter stents for the treatment of saccular middle cerebral artery bifurcation aneurysms. AJNR Am J Neuroradiol 37:279-284, 2016

11. Chalouhi N, Daou B, Kung D, Zanaty M, Phillips JL, Tjoumakaris S, et al: Fate of the ophthalmic artery after treatment with the pipeline embolization device. Neurosurgery 77:581-584, 2015

12. Chalouhi N, Jabbour P, Singhal S, Drueding R, Starke RM, Dalyai RT, et al: Stent-assisted coiling of intracranial aneurysms: predictors of complications, recanalization, and outcome in 508 cases. Stroke 44:1348-1353, 2013

13. Chalouhi N, Starke RM, Yang S, Bovenzi CD, Tjoumakaris $\mathrm{S}$, Hasan D, et al: Extending the indications of flow diversion to small, unruptured, saccular aneurysms of the anterior circulation. Stroke 45:54-58, 2014

14. Chalouhi N, Tjoumakaris S, Starke RM, Gonzalez LF, Randazzo C, Hasan D, et al: Comparison of flow diversion and 
coiling in large unruptured intracranial saccular aneurysms. Stroke 44:2150-2154, 2013

15. Chalouhi N, Zanaty M, Whiting A, Yang S, Tjoumakaris S, Hasan D, et al: Safety and efficacy of the Pipeline Embolization Device in 100 small intracranial aneurysms. J Neurosurg 122:1498-1502, 2015

16. Chitale R, Gonzalez LF, Randazzo C, Dumont AS, Tjoumakaris S, Rosenwasser R, et al: Single center experience with Pipeline stent: feasibility, technique, and complications. Neurosurgery 71:679-691, 2012

17. Chiu AH, Cheung AK, Wenderoth JD, De Villiers L, Rice H, Phatouros CC, et al: Long-term follow-up results following elective treatment of unruptured intracranial aneurysms with the Pipeline Embolization Device. AJNR Am J Neuroradiol 36:1728-1734, 2015

18. Cohen JE, Gomori JM, Moscovici S, Leker RR, Itshayek E: Delayed complications after flow-diverter stenting: reactive in-stent stenosis and creeping stents. J Clin Neurosci 21:1116-1122, 2014

19. Colby GP, Lin LM, Caplan JM, Jiang B, Huang J, Tamargo RJ, et al: Immediate procedural outcomes in 44 consecutive Pipeline Flex cases: the first North American single-center series. J Neurointerv Surg 8:702-709, 2016

20. Colby GP, Lin LM, Gomez JF, Paul AR, Huang J, Tamargo $\mathrm{RJ}$, et al: Immediate procedural outcomes in 35 consecutive Pipeline embolization cases: a single-center, single-user experience. J Neurointerv Surg 5:237-246, 2013

21. Crobeddu E, Lanzino G, Kallmes DF, Cloft HJ: Marked decrease in coil and stent utilization following introduction of flow diversion technology. J Neurointerv Surg 5:351-353, 2013

22. Cruz JP, Chow M, O'Kelly C, Marotta B, Spears J, Montanera W, et al: Delayed ipsilateral parenchymal hemorrhage following flow diversion for the treatment of anterior circulation aneurysms. AJNR Am J Neuroradiol 33:603-608, 2012

23. Deutschmann HA, Wehrschuetz M, Augustin M, Niederkorn $\mathrm{K}$, Klein GE: Long-term follow-up after treatment of intracranial aneurysms with the Pipeline Embolization Device: results from a single center. AJNR Am J Neuroradiol 33:481-486, 2012

24. De Vries J, Boogaarts J, Van Norden A, Wakhloo AK: New generation of flow diverter (Surpass) for unruptured intracranial aneurysms: a prospective single-center study in 37 patients. Stroke 44:1567-1577, 2013

25. Di Maria F, Pistocchi S, Clarençon F, Bartolini B, Blanc R, Biondi A, et al: Flow diversion versus standard endovascular techniques for the treatment of unruptured carotid-ophthalmic aneurysms. AJNR Am J Neuroradiol 36:2325-2330, 2015

26. Fargen KM, Hoh BL, Welch BG, Pride GL, Lanzino G, Boulos AS, et al: Long-term results of Enterprise stent-assisted coiling of cerebral aneurysms. Neurosurgery 71:239-244, 2012

27. Fischer S, Aguilar-Pérez M, Henkes E, Kurre W, Ganslandt $\mathrm{O}$, Bäzner H, et al: Initial experience with p64: a novel mechanically detachable flow diverter for the treatment of intracranial saccular sidewall aneurysms. AJNR Am J Neuroradiol 36:2082-2089, 2015

28. Fischer S, Perez MA, Kurre W, Albes G, Bäzner H, Henkes $\mathrm{H}$ : Pipeline embolization device for the treatment of intraand extracranial fusiform and dissecting aneurysms: initial experience and long-term follow-up. Neurosurgery 75:364374,2014

29. Fischer S, Vajda Z, Aguilar Perez M, Schmid E, Hopf N, Bäzner H, et al: Pipeline embolization device (PED) for neurovascular reconstruction: initial experience in the treatment of 101 intracranial aneurysms and dissections. Neuroradiology 54:369-382, 2012

30. Flores BC, Klinger DR, Rickert KL, Barnett SL, Welch BG,
White JA, et al: Management of intracranial aneurysms associated with arteriovenous malformations. Neurosurg Focus 37(3):E11, 2014

31. Gascou G, Lobotesis K, Brunel H, Machi P, Riquelme C, Eker O, et al: Extra-aneurysmal flow modification following pipeline embolization device implantation: focus on regional branches, perforators, and the parent vessel. AJNR Am J Neuroradiol 36:725-731, 2015

32. Gawlitza M, Januel AC, Tall P, Bonneville F, Cognard C: Flow diversion treatment of complex bifurcation aneurysms beyond the circle of Willis: a single-center series with special emphasis on covered cortical branches and perforating arteries. J Neurointerv Surg 8:481-487, 2016

33. Heller RS, Dandamudi V, Lanfranchi M, Malek AM: Effect of antiplatelet therapy on thromboembolism after flow diversion with the Pipeline Embolization Device. J Neurosurg 119:1603-1610, 2013

34. Hong Y, Wang YJ, Deng Z, Wu Q, Zhang JM: Stent-assisted coiling versus coiling in treatment of intracranial aneurysm: a systematic review and meta-analysis. PLoS One 9:e82311, 2014

35. Iosif C, Camilleri Y, Saleme S, Caire F, Yardin C, Ponomarjova $\mathrm{S}$, et al: Diffusion-weighted imaging-detected ischemic lesions associated with flow-diverting stents in intracranial aneurysms: safety, potential mechanisms, clinical outcome, and concerns. J Neurosurg 122:627-636, 2015

36. Kim LJ, Tariq F, Levitt M, Barber J, Ghodke B, Hallam DK, et al: Multimodality treatment of complex unruptured cavernous and paraclinoid aneurysms. Neurosurgery 74:51-61, 2014

37. Kocer N, Islak C, Kizilkilic O, Kocak B, Saglam M, Tureci E: Flow Re-direction Endoluminal Device in treatment of cerebral aneurysms: initial experience with short-term followup results. J Neurosurg 120:1158-1171, 2014

38. Lanzino G, Crobeddu E, Cloft HJ, Hanel R, Kallmes DF: Efficacy and safety of flow diversion for paraclinoid aneurysms: a matched-pair analysis compared with standard endovascular approaches. AJNR Am J Neuroradiol 33:2158-2161, 2012

39. Levitt MR, Ghodke BV, Hallam DK, Sekhar LN, Kim LJ: Incidence of microemboli and correlation with platelet inhibition in aneurysmal flow diversion. AJNR Am J Neuroradiol 34:2321-2325, 2013

40. Lin N, Brouillard AM, Keigher KM, Lopes DK, Binning MJ, Liebman KM, et al: Utilization of Pipeline embolization device for treatment of ruptured intracranial aneurysms: US multicenter experience. J Neurointerv Surg 7:808-815, 2015

41. Lubicz B, Collignon L, Raphaeli G, De Witte O: Pipeline flow-diverter stent for endovascular treatment of intracranial aneurysms: preliminary experience in 20 patients with 27 aneurysms. World Neurosurg 76:114-119, 2011

42. Lubicz B, Collignon L, Raphaeli G, Pruvo JP, Bruneau M, De Witte O, et al: Flow-diverter stent for the endovascular treatment of intracranial aneurysms: a prospective study in 29 patients with 34 aneurysms. Stroke 41:2247-2253, 2010

43. Lubicz B, Van der Elst O, Collignon L, Mine B, Alghamdi F: Silk flow-diverter stent for the treatment of intracranial aneurysms: a series of 58 patients with emphasis on long-term results. AJNR Am J Neuroradiol 36:542-546, 2015

44. Lylyk P, Miranda C, Ceratto R, Ferrario A, Scrivano E, Luna $\mathrm{HR}$, et al: Curative endovascular reconstruction of cerebral aneurysms with the pipeline embolization device: the Buenos Aires experience. Neurosurgery 64:632-643, N6, 2009

45. Martínez-Galdámez M, Pérez S, Vega A, Ruiz P, Caniego JL, Bárcena E, et al: Endovascular treatment of intracranial aneurysms using the Pipeline Flex embolization device: a case series of 30 consecutive patients. J Neurointerv Surg 8:396-401, 2016 
46. Martínez-Galdámez M, Romance A, Vega P, Vega A, Caniego JL, Paul L, et al: Pipeline Endovascular Device for the treatment of intracranial aneurysms at the level of the circle of Willis and beyond: multicenter experience. J Neurointerv Surg 7:816-823, 2015

47. McAuliffe W, Wenderoth JD: Immediate and midterm results following treatment of recently ruptured intracranial aneurysms with the Pipeline Embolization Device. AJNR Am J Neuroradiol 33:487-493, 2012

48. McAuliffe W, Wycoco V, Rice H, Phatouros C, Singh TJ, Wenderoth J: Immediate and midterm results following treatment of unruptured intracranial aneurysms with the Pipeline Embolization Device. AJNR Am J Neuroradiol 33:164170, 2012

49. Meckel S, McAuliffe W, Fiorella D, Taschner CA, Phatouros C, Phillips TJ, et al: Endovascular treatment of complex aneurysms at the vertebrobasilar junction with flow-diverting stents: initial experience. Neurosurgery 73:386-394, 2013

50. Mocco J, Fargen KM, Albuquerque FC, Bendok BR, Boulos AS, Carpenter JS, et al: Delayed thrombosis or stenosis following enterprise-assisted stent-coiling: is it safe? Midterm results of the interstate collaboration of Enterprise stent coiling. Neurosurgery 69:908-914, 2011

51. Mocco J, Snyder KV, Albuquerque FC, Bendok BR, Alan S B, Carpenter JS, et al: Treatment of intracranial aneurysms with the Enterprise stent: a multicenter registry. J Neurosurg 110:35-39, 2009

52. Möhlenbruch MA, Herweh C, Jestaedt L, Stampfl S, Schönenberger S, Ringleb PA, et al: The FRED flow-diverter stent for intracranial aneurysms: clinical study to assess safety and efficacy. AJNR Am J Neuroradiol 36:1155-1161, 2015

53. Monteith SJ, Tsimpas A, Dumont AS, Tjoumakaris S, Gonzalez LF, Rosenwasser RH, et al: Endovascular treatment of fusiform cerebral aneurysms with the Pipeline Embolization Device. J Neurosurg 120:945-954, 2014

54. Mut F, Scrivano E, Bleise C, Lylyk P, Cebral J: Hemodynamics in two tandem aneurysms treated with flow diverters. Int J Numer Methods Biomed Eng 30:517-524, 2014

55. Nelson PK, Lylyk P, Szikora I, Wetzel SG, Wanke I, Fiorella D: The Pipeline Embolization Device for the intracranial treatment of aneurysms trial. AJNR Am J Neuroradiol 32:34-40, 2011

56. O'Kelly CJ, Spears J, Chow M, Wong J, Boulton M, Weill A, et al: Canadian experience with the Pipeline Embolization Device for repair of unruptured intracranial aneurysms. AJNR Am J Neuroradiol 34:381-387, 2013

57. Piano M, Valvassori L, Quilici L, Pero G, Boccardi E: Midterm and long-term follow-up of cerebral aneurysms treated with flow diverter devices: a single-center experience. J Neurosurg 118:408-416, 2013

58. Pierot L: Flow diverter stents in the treatment of intracranial aneurysms: where are we? J Neuroradiol 38:40-46, 2011

59. Pierot L, Costalat V, Moret J, Szikora I, Klisch J, Herbreteau D, et al: Safety and efficacy of aneurysm treatment with WEB: results of the WEBCAST study. J Neurosurg 124:1250-1256, 2016

60. Piotin M, Blanc R, Spelle L, Mounayer C, Piantino R, Schmidt PJ, et al: Stent-assisted coiling of intracranial aneurysms: clinical and angiographic results in 216 consecutive aneurysms. Stroke 41:110-115, 2010

61. Pistocchi S, Blanc R, Bartolini B, Piotin M: Flow diverters at and beyond the level of the circle of Willis for the treatment of intracranial aneurysms. Stroke 43:1032-1038, 2012

62. Puffer RC, Kallmes DF, Cloft HJ, Lanzino G: Patency of the ophthalmic artery after flow diversion treatment of paraclinoid aneurysms. J Neurosurg 116:892-896, 2012

63. Puffer RC, Piano M, Lanzino G, Valvassori L, Kallmes DF, Quilici L, et al: Treatment of cavernous sinus aneurysms with flow diversion: results in 44 patients. AJNR Am J Neuroradiol 35:948-951, 2014

64. Raphaeli G, Collignon L, De Witte O, Lubicz B: Endovascular treatment of posterior circulation fusiform aneurysms: single-center experience in 31 patients. Neurosurgery 69:274-283, 2011

65. Roessler K, Krawagna M, Dörfler A, Buchfelder M, Ganslandt O: Essentials in intraoperative indocyanine green videoangiography assessment for intracranial aneurysm surgery: conclusions from 295 consecutively clipped aneurysms and review of the literature. Neurosurg Focus 36(2):E7, 2014

66. Saatci I, Yavuz K, Ozer C, Geyik S, Cekirge HS: Treatment of intracranial aneurysms using the pipeline flow-diverter embolization device: a single-center experience with longterm follow-up results. AJNR Am J Neuroradiol 33:14361446,2012

67. Saleme S, Iosif C, Ponomarjova S, Mendes G, Camilleri Y, Caire F, et al: Flow-diverting stents for intracranial bifurcation aneurysm treatment. Neurosurgery 75:623-631, 2014

68. Schneiders JJ, VanBavel E, Majoie CB, Ferns SP, van den Berg R: A flow-diverting stent is not a pressure-diverting stent. AJNR Am J Neuroradiol 34:E1-E4, 2013

69. Shankar JJ, Tampieri D, Iancu D, Cortes M, Agid R, Krings $\mathrm{T}$, et al: SILK flow diverter for complex intracranial aneurysms: a Canadian registry. J Neurointerv Surg 8:273-278, 2016

70. Shapiro M, Becske T, Sahlein D, Babb J, Nelson PK: Stentsupported aneurysm coiling: a literature survey of treatment and follow-up. AJNR Am J Neuroradiol 33:159-163, 2012

71. Sluzewski M, Bosch JA, van Rooij WJ, Nijssen PC, Wijnalda D: Rupture of intracranial aneurysms during treatment with Guglielmi detachable coils: incidence, outcome, and risk factors. J Neurosurg 94:238-240, 2001

72. Szikora I, Berentei Z, Kulcsar Z, Marosfoi M, Vajda ZS, Lee $\mathrm{W}$, et al: Treatment of intracranial aneurysms by functional reconstruction of the parent artery: the Budapest experience with the Pipeline Embolization Device. AJNR Am J Neuroradiol 31:1139-1147, 2010

73. Tanweer O, Raz E, Brunswick A, Zumofen D, Shapiro M, Riina HA, et al: Cavernous carotid aneurysms in the era of flow diversion: a need to revisit treatment paradigms. AJNR Am J Neuroradiol 35:2334-2340, 2014

74. Tähtinen OI, Manninen HI, Vanninen RL, Seppänen J, Niskakangas T, Rinne J, et al: The Silk flow-diverting stent in the endovascular treatment of complex intracranial aneurysms: technical aspects and midterm results in 24 consecutive patients. Neurosurgery 70:617-624, 2012

75. Vedantam A, Rao VY, Shaltoni HM, Mawad ME: Incidence and clinical implications of carotid branch occlusion following treatment of internal carotid artery aneurysms with the Pipeline Embolization Device. Neurosurgery 76:173-178, 2015

76. Wagner A, Cortsen M, Hauerberg J, Romner B, Wagner MP: Treatment of intracranial aneurysms. Reconstruction of the parent artery with flow-diverting (Silk) stent. Neuroradiology 54:709-718, 2012

77. Wakhloo AK, Lylyk P, de Vries J, Taschner C, Lundquist J, Biondi A, et al: Surpass flow diverter in the treatment of intracranial aneurysms: a prospective multicenter study. AJNR Am J Neuroradiol 36:98-107, 2015

78. Xiang J, Ma D, Snyder KV, Levy EI, Siddiqui AH, Meng H: Increasing flow diversion for cerebral aneurysm treatment using a single flow diverter. Neurosurgery 75:286-294, 2014

79. Yavuz K, Geyik S, Saatci I, Cekirge HS: Endovascular treatment of middle cerebral artery aneurysms with flow modification with the use of the Pipeline Embolization Device. AJNR Am J Neuroradiol 35:529-535, 2014

80. Yoon JW, Siddiqui AH, Dumont TM, Levy EI, Hopkins LN, Lanzino G, et al: Feasibility and safety of Pipeline Emboliza- 
tion Device in patients with ruptured carotid blister aneurysms. Neurosurgery 75:419-429, 2014

81. Zhang Y, Zhou Y, Yang P, Liu J, Xu Y, Hong B, et al: Comparison of the flow diverter and stent-assisted coiling in large and giant aneurysms: safety and efficacy based on a propensity score-matched analysis. Eur Radiol 26:2369-2377, 2016

82. Zhou G, Su M, Zhu YQ, Li MH: Efficacy of flow-diverting devices for cerebral aneurysms: a systematic review and meta-analysis. World Neurosurg 85:252-262, 2016

83. Zhou G, Zhu YQ, Su M, Gao KD, Li MH: Flow-diverting devices versus coil embolization for intracranial aneurysms: a systematic literature review and meta-analysis. World Neurosurg 88:640-645, 2016

84. Zhou Y, Yang PF, Fang YB, Xu Y, Hong B, Zhao WY, et al: A novel flow-diverting device (Tubridge) for the treatment of 28 large or giant intracranial aneurysms: a single-center experience. AJNR Am J Neuroradiol 35:2326-2333, 2014

\section{Disclosures}

The authors report no conflict of interest concerning the materi- als or methods used in this study or the findings specified in this paper.

\section{Author Contributions}

Conception and design: Li. Acquisition of data: Zhou, Su. Analysis and interpretation of data: Zhou, Su. Drafting the article: Zhou, Su. Critically revising the article: Li, Yin. Reviewed submitted version of manuscript: Li, Yin. Approved the final version of the manuscript on behalf of all authors: Li. Statistical analysis: Zhou, Su. Administrative/technical/material support: Yin. Study supervision: $\mathrm{Li}$.

\section{Correspondence}

Ming-Hua Li, Department of Diagnostic and Interventional Radiology, Shanghai Jiao Tong University Affiliated Sixth People's Hospital, 600 Yi Shan Rd., Shanghai 200233, China. email: liminghuayx@126.com. 